\title{
IMPACT OF GOVERNANCE PERFORMANCE ON THE INDONESIAN MAP STANDARIDISING PROCESS
}

\author{
N Z Muhamad a, R H Koestoera \\ ${ }^{a}$ School of Environment, University of Indonesia, Indonesia
}

Article Info:

Received: 2 August 2017

in revised form: 10 Dec 2017

Accepted: 30 January 2018

Available Online: 25 April 2018

Keywords:

Thematic map, land rights, land conlflict, sustainable

development

Corresponding Author: Nabiha Zain Muhamad

School of Environment, University of Indonesia, Indonesia

Email: nabiha.shahab@gmail.com

\begin{abstract}
The lack of standardized thematic maps in Indonesia has led to many land ownerships conflicts on the ground. The problem began since Indonesia started to exploit its natural resources by giving up its management to the market in the early 1960s. Concessions to exploit natural resources were given out without adequate assessment to real potential value of the resources. Mapping of concession areas by respective ministries without any standardized method or reference lead to the production of multiple official maps that conflict one another. Efforts to standardize the conflicting maps were initiated in 2011 and is currently still ongoing. This study aims to derive governance performance indices that directly or indirectly affect the map standardizing process. This study interviewed sources related to either the policy making process at the national level; government officials executing the policy at the provincial level and those affected by the conflict and other stakeholders advocating their rights. Interviewees include a number of officials in the central government both current and when the initiative were launched, provincial government and at the village level. To achieve sustainable development in environmental management, good governance is a prerequisite. However, the study found that sectoral ego and low government performance including, among others, corruption played a big role in hindering the process. By adding governance performance indices along with natural and economic variables to a forecast model, it can be predicted when Indonesia will likely to achieve its ideal level of harmonized maps.
\end{abstract} process, 5(1), 157-162. doi: 10.14710/geoplanning.5.1.157-162

\section{INTRODUCTION}

The lack of standardized thematic maps in Indonesia has led to many land ownership conflicts on the ground (Riggs et al., 2016; Wibowo \& Giessen, 2015). Uncertainty of land ownership, including those caused by overlapping maps, lead to the uncertainty of land ownership. Insufficient protection on these lands and also on protected land resulted in to encroachments and illegal occupation that eventually increase the risk of forest degradation and fires (Tsujino et al,.2016)

Years of inconsistent use of references and standards in producing maps had caused overlapping borders on the ground. Different government agencies issued licenses for land utilization generated their own maps. To issue forest concessions and establishing protected areas, for example, the Ministry of Forestry. The Ministry of Energy and Mineral Resources would generate their own maps as their reference in issuing mining licenses. The same situation was true for the National Land Agency when issuing land tenures, and so on.

The problem began as early as the 1960s when Indonesia started to exploit its natural resources by giving up its management to the market. Concessions to exploit natural resources were given out without adequate assessment to real potential value of the resources (Kartodihardjo, 2015).

In 2013, (FWI, 2013) found 14.7 million hectares of overlapping licenses for forest concessions, industrial forest plantations and mining areas. They also found that around seven million hectares of land covered by natural forest is located on land with conflicting licenses between forest concessions, industrial 
forest and oil palm plantations and mining areas. recorded an. At least 472 agrarian conflicts all over the country in more than 2.8 hectares of land, after a recorded increasing trend of agrarian conflicts (KPA, 2014), with most of the conflicts located in plantation areas.

Efforts to standardize the conflicting maps were initiated in 2011 and is currently still ongoing. In 2016, the government issued a directive to bring all government bodies that generate maps. The policy is also known as the 'One Map Policy' (Riggs et al., 2016; Wibowo \& Giessen, 2015).

Sources related the policy making process and those affected by the conflict and other stakeholders advocating their rights were interviewed in this study. The aim is to gain insight on the dynamics of related policies and how it affects progress of the map standardizing process and then derive governance performance indices that directly or indirectly affect the map standardizing process. This study hopes to contribute in better planning through identifying constraints and finding solutions in the process of map standardizing.

\section{DATA AND METHODS}

\subsection{Analytical framework}

Through the cause of this study, we found that a rich reference to the state of the Indonesian land tenure structure and its problems have been published (Duchelle et al., 2014; Resosudarmo et al., 2014; Sloan, 2014; Sunderlin et al., 2014; Wicke et al., 2011; Yusran et al., 2017)

However, specific studies on the One Map Policy and its performance is somewhat limited. In this study we interviewed people related to the policy making process from its inception around 2011 and started to measure performance since the One Map Policy was stipulated as regulation in 2016.

We analyze regulatory performance by measuring realization of specific policy targets. The baseline study permits us to evaluate the latest progress of the One Map policy implementation and what factors influence its performance. This information will allow us to derive performance indices that will be fed into a forecast model in a future study.

\subsection{Case selection}

This study interviewed sources related to either the policy making process at the national level; government officials executing the policy at the provincial level and those affected by the conflict and other stakeholders advocating their rights. Interviewees include a number of officials in the central government both current and when the initiative were launched, provincial government and at the village level. Interviews were conducted in the period between May and August 2016.

Three informants are currently at the policy making level, and one were in charge of overseeing the policy during the previous administration. Three informants were officials at the provincial and village level and three other informants represent non-government organizations.

\section{RESULTS AND DISCUSSION}

\subsection{History of Indonesia's One Map Policy}

The effort to standardize Indonesia's maps, or the One Map initiative were initiated in the context of a bilateral agreement with Norway on a program to prepare Indonesia to participate in the REDD+ scheme(The Government of the Kingdom of Norway and the Government of the Republic of Indonesia, 2010). The main programme under this agreement are efforts to reform forest governance.

At the time, primary forest maps generated by different ministries showed startlingly different results. The differences were caused by different definitions of forest and different mapping methodologies. Compensations under the REDD+ scheme demand measurable results which means there is a need for a clear and non-conflicting forest maps (Duchelle et al., 2014)

By May 2011 the Indonesian government issued a two-year moratorium on the issuance of new licenses for land utilisation on forests and peatlands. By placing the moratorium, the government hoped to slow 
down deforestation - in theory, during the moratorium period. In parallel, during that period, the UKP4 initiated a process of integrating maps, regulations and utilisation permits in an initiative dubbed the 'One Map' process (Sloan, 2014)

The initiative has four aims: one reference, one standard, one database and one geoportal. It aims to digitise data and information related to primary and secondary forests including peatlands on a single portal and synchronised with licenses data attached to the land area, with the urgency to eliminate duplicate licenses issued for the same land area.

There were no regulation that binds related government agencies to work together to achieve the goals of this initiative, but the UKP4 used their coercive power to bring every ministry together in one table to solve the problem. At least 14 ministries have been involved in the implementation of One Map. The UKP4, brought ministries together in an effort to make everyone comfortable and gain trust to share their agency's data with others (Wibowo \& Giessen, 2015)

Earlier efforts to integrate data were made a number of years before the One Map Policy was introduced. In 2007, the Presidential Regulation no. 85/2007 on the establisment of a National Spatial Data Network (JDSN) in 2007, aims to create an integrated data hub. The regulation had not made much progress in terms of its objectives. It was later replaced by Presidential Regulation no. 27/2014 on National Geospatial Information Network.

One of the first moves to meet the demand for accurate, responsible and accessible geospatial information was the establishment of the Geospatial Information Agency, Badan Informasi Geospasial, or BIG. It became the only agency authorised to provide the country's base map, or Basic Geospatial Information. The geoportal, was to be hosted by the BIG. The agency was also given the mandate to provide an implementation strategy and funding for basemaps at various scales, from the smaller scale like those for school atlases to more detailed maps for urban planning or other ground level infrastructure projects.

A few months later a direction was made to map peatlands using the Standar Nasional Indonesia (SNI) or Indonesian National Standard on land cover to ensure the production of a complete-overlap map, avoiding different ministries to use different definitions and standards. It was decided that subsequent maps would then be updated using high spatial resolution satellite imagery.

Law No 4/2011 was derived into two regulations governing its implementation (Government Regulation no 9/2014 regarding the implementation of Law no 4/2011 and Presidential Regulation no 27/2014 on the National Geospatial Information Network). During the four years since the One Map initiative were launched, most work was done in discussing the idea and starting communication between ministries that had worked mutually exclusively before. The initiative became policy in 2016 under a Presidential Decree.

\subsection{Implementation under the current government}

The One Map Policy was officially launched as a regulation with Presidential Decree No. 9/2016. The decree appoints a 'One Map acceleration team' and a 'One Map implementation team'. It also spells out specific targets until 2019.

The One Map acceleration team, led by the Coordinating Minister for Economic Affairs, has the task of strategically coordinating implementation of the policy. This includes setting policies, monitoring, and evaluation of the implementation of the one map policy. While the One Map implementation team, chaired by the Head of BIG has the task of technically coordinating implementation of the policy.

The target is to have all 85 thematic maps compiled and integrated in the official base maps, and available to the public by the end of 2019. By mid-2016, all targeted 85 thematic maps have been collected. The collected maps are then verified by BIG before integrated into the standard base maps. However, the target of integrating these thematic maps correctly on a one reference base map is behind schedule. The last stage of the one map process is synchronising all thematic maps, that have been integrated to the base maps.

Even though the One Map Policy stipulated the formation of a synchronisation team, this study found that the team may not start working before 2019 , or the end of the current administration. 


\subsection{Implementation level}

The One Map policy is essentially working to syncronise maps at the government level and work its way down. At the initial stages, the provincial level were involved mainly in the effort to collect land utilisation permits (UKP4, 2013).

At the village level, many have not mapped their area properly. As a result, local residents have no control over who utilises their land (Riggs et al., 2016) In the early 1990s, participatory mapping movement started with the community of Long Uli in Malinau, North Kalimantan (Deddy, 2006) Today the movement is national in scope.

Permits were issued haphazardly since the decentralisation gave mandate to local governments manage their own natural resources. Permits issued from the central or regional government sometimes are not attached with detailed site plans or preceded with proper surveys on the ground. The lack of a reference map has triggered space utilisation conflicts in a number of sectors, including forestry, mining, agriculture, and land tenure (Harahap et al,. 2017).

\subsection{Non-governmental organizations' role}

Non-governmental role is mainly working to advocate the rights of indigenous people that are at the bad end of the conflict. For example, the Ancestral Domain Registration Agency (BRWA) is an organisation set up by a number of NGOs to pool results of customary land mapping. BRWA was set up to consolidate the indigenous community's maps into one registry system and database. The Registry is not only used in the incidental cases of conflicts but also in the customary land recognition process.

BRWA regularly submits the community maps to different Ministries and, with their latest submissions in March 2016, they handed 665 community maps covering around 7.4 million hectares to the Government, including to the Ministry of Environment and Forestry, Ministry of Interior Affairs, the Ministry of Agrarian Affairs and Spatial Planning and the newly formed Peatland Restoration Agency. In the process of detailing the maps, it showed that the government's data lacked key information needed to improve the quality of maps. This is information that could and should have come from the community.

\subsection{The success of the use of One Map}

The success of the use of One Map will to a large degree be determined by the availability of information on utilization rights such as timber and mining concessions, plantation etc. If this information is readily available in the public domain then the public can monitor whenever there are violations thus helping avoid issuing rights over existing rights.

The study found that since the policy is very much a centralized policy, politics played a big role in the course of its implementation. Problems with the overlapping maps were common knowledge, but little was actually done on the ground to solve the problem.

During the President Susilo Bambang Yudhoyono's administration the One Map policy was launched as a test case. With the issuance of the Presidential Decree number 9/2016, it is now implemented nationally. However, the study found that budget allocation and changes in policy direction away from the set targets have actually slowed down progress of the policy.

A recent major cut in state budgets across ministries has cast doubt on whether progress will stay on schedule. At this stage there is uncertainty on how these cuts will impact schedules for further development of One Map. For instance, BIG gets to keep their budget for their One Map work, while other ministries, such as the Coordinating Ministry for Economic Affairs, that leads the One Map Policy Acceleration team (as assigned by Presidential Decree no.9/2016), has had their budget slashed. They have had to drop plans to organize one map trainings, clinics until the end of the year.

Five years on since the first initiative was introduced to the Indonesian public, efforts to tidy up the country's maps seems to be progressing at snail pace. However, on the positive side, there is a high commitment from the highest level of government, backed with a firm legal basis. This serious commitment should be supported by a secured budget to ensure no more set back on the process. Aside from all the formal framework, in the journey towards achieving one map for Indonesia, there needs to be highly 
committed individuals to continue to break the tradition of working in isolation and cooperate between ministry and government institutions. This more personal approach will ensure that less resistance, if any, can be reduced for the policy to reach its targets by the end of 2019.

The next big challenge is to continue to the final stage to synchronize all the conflicting maps at the ground level. The current process should be coupled by a bottom-up process, where locally-based initiatives need to solve site-specific problems, involving all conflicting parties. This process may need new innovations in policy and social engineering.

\section{CONCLUSION AND FURTHER WORK}

\subsection{Conclusion}

To achieve sustainable development in environmental management, good governance is a prerequisite. However, a lack of communication and exclusiveness between ministries and low government performance including, among others, corruption played a big role in hindering the process. By adding governance performance indices along with natural and economic variables to a forecast model, it can be predicted when Indonesia will likely to achieve its ideal level of harmonized maps.

\subsection{Further work}

The next step of this study is to build a forecast model of spatial dynamics in areas with overlapping tenure maps. Aside from environmental variables, the model will include governance variables such as governance performance and corruption perception.

\section{REFERENCES}

Deddy, K. (2006). Community Mapping, Tenurial Rights and Conflict Resolution in Kalimantan. In State, Communities and Forests In Contemporary Borneo. Press [Crossref]

Duchelle, A. E., Cromberg, M., Gebara, M. F., Guerra, R., Melo, T., Larson, A., Sunderlin, W. D. (2014). Linking Forest Tenure Reform, Environmental Compliance, and Incentives: Lessons from REDD in the Brazilian Amazon. World Development, 55, 53-67 [Crossref]

FWI. (2013). FWI's Portrait of Indonesia's Forest.

Harahap, F., Silveira, S., \& Khatiwada, D. (2017). Land allocation to meet sectoral goals in Indonesia-An analysis of policy coherence. Land Use Policy, 61, 451-465. [Crossref]

Kartodihardjo, H. (2015). Forest and Land Fires: Adverse Impacts of Licensing Governance.

KPA. (2014). Catatan Akhir Tahun Konsorsium Pembaruan Agraria 2014. "Membenahi Masalah Agraria: Prioritas Kerja Jokowi-JK Pada 2015."

Resosudarmo, I. A. P., Atmadja, S., Ekaputri, A. D., Intarini, D. Y., Indriatmoko, Y., \& Astri, P. (2014). Does Tenure Security Lead to REDD+ Project Effectiveness? Reflections from Five Emerging Sites in Indonesia. World Development, 55, 68-83. 5 [Crossref]

Riggs, R. A., Sayer, J., Margules, C., Boedhihartono, A. K., Langston, J. D., \& Sutanto, H. (2016). Forest tenure and conflict in Indonesia: Contested rights in Rempek Village, Lombok. Land Use Policy, 57, 241249. [Crossref]

Sloan, S. (2014). Indonesia's moratorium on new forest licenses: An update. Land Use Policy, 38, 37-40 [Crossref]

Sunderlin, W. D., Larson, A. M., Duchelle, A. E., Resosudarmo, I. A. P., Huynh, T. B., Awono, A., \& Dokken, T. (2014). How are REDD Proponents Addressing Tenure Problems? Evidence from Brazil, Cameroon, Tanzania, Indonesia, and Vietnam. World Development, 55, 37-52. [Crossref]

Tsujino, R., Yumoto, T., Kitamura, S., Djamaluddin, I., \& Darnaedi, D. (2016). History of forest loss and degradation in Indonesia. Land Use Policy, 57, 335-347. [Crossref]

UKP4. (2013). Laporan Pemantauan Instruksi Presiden No. 10/2011: Hasil Capaian dan Tindak Lanjut.

Wibowo, A., \& Giessen, L. (2015). Absolute and relative power gains among state agencies in forest-related land use politics: The Ministry of Forestry and its competitors in the REDD+Programme and the One Map Policy in Indonesia. Land Use Policy, 49, 131-141. [Crossref] 
Wicke, B., Sikkema, R., Dornburg, V., \& Faaij, A. (2011). Exploring land use changes and the role of palm oil production in Indonesia and Malaysia. Land Use Policy, 28(1), 193-206. [Crossref]

Yusran, Y., Sahide, M. A. K., Supratman, S., Sabar, A., Krott, M., \& Giessen, L. (2017). The empirical visibility of land use conflicts: From latent to manifest conflict through law enforcement in a national park in Indonesia. Land Use Policy, 62, 302-315. [Crossref] 